\title{
BOŠNJACI I HADIS OD AUSTRO-UGARSKE OKUPACIJE BIH DO DANAS
}

\section{Sažetak}

Iako su dolaskom Osmanlija $i$ islamizacijom Bosne hadis $i$ hadiska znanost definirani u potpunosti, gledano kroz prizmu napisanih djela o teoriji hadisa, hadiskoj terminologiji, završetku brojnih zbirki hadisa i drugo, ipak se bošnjački intelektualci nisu time zadovoljili, već su svojom znatiželjom i intelektualnim potencijalima dali svoj doprinos i u ovoj znanstvenoj oblasti.

Ovaj tekst pokušava osvijetliti angažman Bošnjaka na polju hadisa $i$ hadiskih disciplina od Austro-ugarske okupacije BiH do danas. On dokazuje da Bošnjaci, iako mali narod, ne zaostaju iza ostalih naroda u pogledu zainteresiranosti za islamske discipline, napose hadis, njegovo očuvanje $i$ prenošenje na generacije koje kasnije dolaze.

Ključne riječi: hadis, hadiske znanosti, Bošnjaci, period AustroUgarske vladavine, period nakon austrougraske dominacije.

\section{UVOD}

Malo je islamskih znanosti u čijem razvoju i profiliranju i Bošnjaci nisu dali svoj značajan doprinos. Iako se naučno-istraživački napor Bošnjaka na području hadisa čini neznatnim dijelom u ukupnom naučno-teorijskom iskustvu muslimanskog svijeta uopće, on, ipak, predstavlja, značajan doprinos tom iskustvu.

Značajno je naglasiti da je naša domovina iznjedrila značajan broj učenjaka u ovoj oblasti. Ako analiziramo Handžićevo djelo ElDževheru-l-esna fi teradžimi 'ulemi ve šu'arai-l-Bosna u kojem on navodi biografije 220 bošnjačkih učenjaka koji su iza sebe ostavili djela na arapskom, turskom i perzijskom jeziku, doći ćemo do fascinantnih podataka. Dobar broj njih se zanimao za hadis i iza sebe ostavio djela iz ove discipline.

\footnotetext{
${ }^{1}$ Islamski pedagoški fakultet Univerziteta u Zenici.
} 
Ako se uzme u obzir postojanje respektabilnog broja hadiskih škola u našim krajevima, poput onih u Livnu, Pruscu, Mostaru, Sarajevu, Nevesinju i Banjoj Luci, nesumnjivo se dolazi do konstatacije do koje je došao i Evlija Čelebija, zaključivši da je i u Bosni postojao, kao i u svim muslimanskim zemljama, veliki broj hadiskih institucija, zvanih Daru-l-hadis, u kojima se čitao i tumačio tekst pojedinih hadiskih zbirki. ${ }^{2}$

Iako Tajib Okić smatra da su Bošnjaci, kada je u pitanju ovaj drugi izvor islama, zauzeli najskromnije mjesto, ${ }^{3}$ ipak se iz navedenog može doći do zaključka, da ni Bošnjaci nisu puno zaostajali za drugim dijelovima islamskog svijeta. Bošnjački muhaddisi Muhammed alBosnevi (umro 1572. god), Ahmed Vali (1598), Muhammed b. Musa el-Bosnevi es-Saraji, zvani Allamek (1635), Derviš 'Ali b. Mustafa elBosnevi el-Hanefi el-Halveti (1640), Osman b. Ibrahim el-Bosnevi, Abdullah b. Muhammed Muhtešim Šaban-zade el-Bosnevi, Ahmed elMostari (17-18. stoljeće), Mustafa Pruščak (1755) i drugi iz osmanskog perioda i Muhammed Tufo, Tajjib Okić i Mehmed Handžić iz novijeg perioda, na najbolji način demantiraju mišljenje Tajiba Okića.

Međutim, mora se priznati da njihov doprinos u ovom domenu nije do sada dovoljno istražen, niti je istinski valoriziran. Dr. Safvetbeg Bašagić, Mehmed Handžić, Tajjib Okić, dr. Hazim Šabanović, dr. Omer Nakićević, dr. Adnan Silajdžić, dr. Zuhdija Hasanović i drugi osvijetlili su, svojim radovima, neke segmente doprinosa bošnjačkih intelektualaca na očuvanju i pravilnom interpretiranju drugog izvora šerijatskog prava. S pravom je očekivati da će mlađi istraživači otići još korak dalje u detaljnijem rasvjetljavanju ovog, ne malog doprinosa bošnjačkih znanstvenika ukupnoj hadiskoj znanosti.

\footnotetext{
${ }^{2}$ Vidi o tome: Evlija Čelebija, Putopis, str. 109, 133 i 412; dr. Omer Nakićević, Uvod u hadisku znanost, str. 67. i Šefik Kurdić, El-'Inaje bi-l-hadisi fi-l-Bosna munzu fethiha ila evahiri-l-karni-l-išrin, neobjavljena doktorska disertacija, str. 233.-238.

${ }^{3}$ Provjeri: Tajib Okić, Islamska tradicija, str. 33.
} 


\section{DOPRINOS BOŠNJAKA HADISKOJ ZNANOSTI ZA VRIJEME AUSTRO-UGARSKE OKUPACIJE}

Bosna i Hercegovina je bila prenapučena poviješću i ogromnim povijesnim teretom u XIX. i XX. stoljeću. Od smjene civilizacija 1878. godine, pa do najvećeg antibosanskog rata u XX stoljeću - onog od 1992 - 1995. - Bosnu i Hrecegovinu u ciklusima od trideset ili četrdeset godina potresaju sveobuhvatne, najčešće ratne, mijene. Upravo se ta nestalnost osjetila u promišljanju islama $\mathrm{u} \mathrm{BiH} \mathrm{i} \mathrm{kod}$ Bošnjaka. Nova razdoblja značila su i nova, odnosno druga pitanja, nove, odnosno drugačije institucije, nove, odnosno druge ljude, ukratko - nove tokove mišljenja.

$\mathrm{BiH}$ je u XX. stoljeću imala svoja središta i krugove uravnoteženog intelektualnog rada i djelovanja (Sarajevo, Zenica, Mostar, Tuzla) u kojima su se okupljali svjetovni muslimanski intelektualci i ulema, zajedno osnivali svoje listove i bavili se, manje ili više, islamom kao moralnom inspiracijom, islamom kao obrascem kulturnog preporoda Bošnjaka i sl. U takve listove spadaju Behar, Biser, Novi Behar.

Svi bošnjački listovi apostrofirali su progres našeg naroda, premda je svaki od njih smatrao da će doći do progresa na različite načine. Neki zabranom prevođenja Kur'ana, odbranom institucija halife i hilafeta i striktnim slijeđenjem Kur'ana i Sunneta, a drugi prevođenjem Kur'ana, uklapanjem $u$ druge tokove političkodruštvenog života, bez povratka i aktualiziranja povratka na hilafet i razumijevanjem Kur'ana i Sunneta u kontekstu novih društvenih, kulturnih i civilizacijskih vrijednosti, u dobroj mjeri se oslanjajući na naučna i tehnološka otkrića.

Valja napomenuti, da su Bošnjaci u XX. stoljeću, u velikoj većini, u pisanju svojih islamskih djela prešli sa upotrebe arapskog, turskog i perzijskog jezika na svoj bosanski jezik. Tako su, u ovom periodu, prvi put obrađene važne teme islama na bosanskom jeziku na latiničkom ili ćiriličkom pismu. To, naravno, nije moglo proći bez duhovnih i društvenih potresa.

$\mathrm{Na}$ malom bh. prostoru izrastao je i stasao veliki broj značajnih ličnosti koje se s pravom mogu nazvati velikim islamskim misliocima. Džemaludin Čaušević je bio ponos bosanskih muslimana i jedna od 
najizraslijih islamskih ličnosti u prvoj polovini XX. stoljeća. On je, kao i mnogi drugi islamski obnovitelji, reformatori i prosvjetitelji, bio novinar, publicist-eklektik, glavni urednik novina, izdavač i pokretač izdavačkih projekata, vjerski lider, vaiz... Pokrenuo je časopise Muallim (izlazio od 1910. - 1913.); Tarik (izlazio od 1908. - 1910.), a neko vrijeme je bio i urednik slavnoga časopisa Behar (izlazio od 1900. - 1911.), da bi izuzetno marljivo promovirao Novi Behar izlazio od 1927. - 1945.). ${ }^{4}$

U svim tim listovima često je bilo govora i o hadisu, a nerijetko su brojni hadisi aktualizirani i komentirani za potrebe različitih tema $\mathrm{i}$ tematskih cjelina.

Treba potcrtati da su sva hadiska djela, posebno hadiske zbirke, u vrijeme Osmanlija već bile sakupljene i valorizirane, onda nije bilo posebne potrebe za tom vrstom aktivnosti u periodu Austro-Ugarske okupacije $\mathrm{BiH}$ i neposredno nakon toga.

Otuda $\mathrm{u}$ periodu nakon Austro-Ugarske okupacije pa do današnjih dana nalazimo najviše autora koji sakupljaju, iz već valoriziranih hadiskih zbirki, uglavnom zbirke od četrdeset hadisa, a nakon toga najviše se angažiralo na prevođenju hadisa $\mathrm{s}$ arapskog jezika ili njegovom komentiranju.

Možemo slobodno kazati da su Bošnjaci, podjednako sa ostalim muslimanskim narodima, bili angažirani u čuvanju, njegovanju i prenošenju drugog izvora šerijatskog prava.

Njihovu brigu na prenošenju ove znanosti na generacije koje slijede, najbolje ilustriraju brojni primjeri mnogih Bošnjaka, koji su svojim pisanjem respektabilnog broja knjiga i tekstova doprinijeli upoznavanju i razvoju ove znanosti u našim krajevima.

Analizirajući djela i tekstove bošnjačkih intelektualaca u periodu između Austro-Ugarske okupacije $\mathrm{BiH}$ i Prvog svjetskog rata, dolazimo do zaključka, da je zanimanje za hadis i hadisku znanost bio sveden na najmanju moguću mjeru, a to je i razumljivo kada se uzme $\mathrm{u}$ obzir nagla transformacija iz jednog pisma $u$ drugo i iz jednog kulturno-civilizacijskog kruga u drugi.

\footnotetext{
${ }^{4}$ Novi Behar su uređivali Husejn Đogo, Edhem Mulabdić, Alija Nametak, Maksim Svara, Fehim Spaho i Abdurahman Mešić.
} 
Otuda, u ovom periodu, pored predmeta hadisa, koji se redovno izučavao u medresema i povremeno predavao $u$ džamijama ili specijaliziranim školama, možemo navesti izbor i komentare hadisa:

- Stotinu i jedan hadis. Autor je Safvet-beg Bašagić. On je u časopisu Behar, objavljivao u nastavcima tekstove pod nazivom Sto $i$ jedan hadis $i$ šerif. Nažalost, uspio je obraditi samo 15 hadisa, jer je dobio zabranu pisanja od strane tadašnjih vlasti i uleme. ${ }^{5}$

Očigledno, nezadovoljan načinom na koji je početkom XX. stoljeća jedan dio bosanske uleme, tumačio islam, Bašagić se odlučio na samostalno tumačenje nekih hadisa, te je od prvog maja 1903. god., $\mathrm{u}$ časopisu Behar, počeo u nastavcima objavljivati tekstove pod nazivom Sto i jedan hadis $i$ šerif.

Bašagić je odmah naglasio da je svoja tumačenja hadisa zasnivao na sakupljenim uglednim (muteber) knjigama, izdvajajući, pri tome, posebno dvije zbirke hadisa: Buharijevu i Muslim-elNišaburijevu. Osim ovih zbirki, Bašagić je istaknuo još četiri zbirke: Tirmizin El-Džami' i tri Sunen-a, i to od Ebu-Davuda, Nesâije i Ibni Madže. ${ }^{6}$

To je učinio znajući da će „neki“ sumnjati u njihovu vjerodostojnost, te je posredno ukazao da je šest najuglednijih zbirki hadisa potpuno ili djelimično čitao na originalnim jezicima.

$\mathrm{O}$ tome nalazimo u jednoj kratkoj bilješci u kojoj odgovara svojim čitaocima i svojim ortodoksnim protivnicima iz hodžinske kurije, ${ }^{7}$ koji su se pobunili zašto se jedan laik miješa u poslove uleme: Na želju mnogih čitatelja Behara i na prigovor nekih i nekih, da moji hadisi nijesu sakupljeni po priznatim vrelima u učenom svijetu, odlučih se da ubuduće donosim u transkripciji originale hadisi šerifa $i$ vrela odakle sam ih uzeo. ${ }^{8}$

\footnotetext{
5 Mulabdić, Edhem, Dvostruka cenzura radi Safvet-bega, Novi Behar, br. 19-21, Sarajevo, 1933-34. god., str. 308.

${ }^{6}$ Bašagić, Safvet-beg, Sto i jedan hadis i šerif, Behar, Br. 1, God. IV, Sarajevo, 1903. god., str.1-2.

7 Ovaj termin hodžinska kurija podrazumijevao je islamski obrazovanu ulemu, imame i mu'allime i bio je poznat u to vrijeme.

${ }^{8}$ Bašagić, Safvet-beg, Cit. izvor, str. 2.
} 
Vjerovatno bi kozervativna hodžinska kurija i oprostila Bašagiću zbog tumačenja pojedinih hadisa, ali mu nije mogla oprostiti način, odnosno metodologiju tog tumačenja. S obzirom da je Bašagić u svoja tumačenja, redovno unosio i svoju erudiciju i ogromno znanje iz različitih društvenih i naučno-kulturnih djelatnosti: filozofije, historije, filologije, književnosti, historije svjetskih religija i dr. Bašagićevo očitovanje takvih znanja za konzervativne „ahmedijaše“, bilo je samo nadmeno hvaljenje i otvorena provokacija.

Međutim, Bašagiću to nije bio glavni cilj, već način da posredno kritizira konzervativne metode pomoću kojih su bosanske hodže tumačile i propagirale islam.

Bašagićevo uvjerenje je bilo da se tumačenje islama, kao univerzalne vjere i načina življenja, u Bosni i Hercegovini generalno mora modernizirati, što bi značilo da hodže, osim vjerskog, moraju imati i temeljno svjetovno obrazovanje, te ići ukorak sa svim savremenim tokovima u životu i društvu, posebno u domenu kulture i nauke. Naravno, ovo je za hodžinsku kuriju u Bosni bilo i više nego zahtjevno i gotovo isto kao novotarija u vjeri, pa su sa otvorenim negodovanjem dočekali Bašagićevo tumačenje hadisa. ${ }^{10}$

Mada je Bašagić naumio svoj serijal tekstova o hadisima napisati kao Sto $i$ jedan hadis $i$ šerif, on je uspio protumačiti tek 15 hadisa, kroz 21 nastavak u časopisu Behar.

Prilikom pažljivog proučavanja njegovog rada, mogli bismo navesti određene zamjerke njegovog tumačenja Sto i jednog hadis $i$ šerifa:

- Bašagić u tumačenju hadisa nije navodio podatke o izvorima i nazivima djela kojima se koristio pri tumačenju hadisa.

Smatramo da nije bilo potrebe da Bašagić navodi izvore i nazive djela s obzirom da je ovo upućeno uglavnom običnom puku, kojem ti podaci ne bi ništa značili.

- Autor nam također, nije navodio sened ${ }^{11}$ hadisa.

\footnotetext{
${ }^{9}$ Ovako su u to vrijeme nazivali muslimansku tradicionalnu ulemu.

${ }^{10}$ Džanko, Muhidin, Safvet-beg Bašagić, Sarajevo, 2006. god., str. 218.

${ }^{11}$ Sened je niz ljudi preko kojih je prenešen određeni hadis.
} 
Mišljenja smo da ni sened nije navodio iz istih razloga kao ni izvore, a sve hadise prenosio je iz originalnih zbirki koje je posjedovao u svojoj porodičnoj biblioteci.

- Hadisi su navođeni na bosanskom jeziku, bez arapskog teksta, koji je koristio za određene hadise napisane u formi transkripcije, latiničnim pismom, koje je navodio u fusnoti.

S obzirom da je hadise objavljivao u časopisu, koji je štampan na bosanskom jeziku, držimo da nije bilo potrebe hadise navoditi na arapskom jeziku.

- Korištenje apokrifnih hadisa.

Bašagić je koristio uglavnom pouzdane predaje, ali da bi u obradi određene teme pojasnio na što bolji način, nekada bi naveo i slabu predaju hadisa, što je uglavnom bio izuzetak, a ne pravilo.

- Nepostojanje valorizacije hadisa.

- Preopširnost u tumačenju.

Neki hadisi obrađivani su u dva, pa čak i u tri broja časopisa Behar. To najzornije ilustruje podatak da je tumačenje 15 hadisa objavljeno na 72 stranice.

- Jedan hadisi šerif. Autor je Muhammed Seid Serdarević. Komentar ovog hadisa je objavljen kao zasebna brošura u izdanju Prve muslimanske nakladne knjižare i štamparije, u Mostaru 1914. god. $^{12}$

\section{DOPRINOS BOŠNJAKA HADISKOJ ZNANOSTI OD PRVOG DO DRUGOG SVJETSKOG RATA}

U ovom periodu zanimanje za hadis i hadiske znanosti bilo je nešto uočljivije nego u prethodnoj fazi. Otuda, možemo spomenuti slijedeća djela iz domena hadisa koja su nastala u tom periodu:

\footnotetext{
${ }^{12}$ Vidi o tome: hfz. Mahmud Traljić, Istaknuti Bošnjaci, str. 300. i Šefiki Kurdić, AlInaya bi al-hadith fi al-Bosna munzu fathiha ila awahir al-qar al- išrin, neobjavljena doktorska disertacija, odbranjena na Univerzitetu Al-Zaituna u Tunisu, 1997. god., str. 131.
} 
- Skovani i patvoreni hadisi. Autor je Muhammed Džemaluddin Čaušević (1870. - 1938.). Ovo je prvi tekst koji tretira apokrifne hadise i upozorava na njihovu štetnost na bosanskome jeziku. ${ }^{13}$

- Uvod u tefsirsku i hadisku nauku: Handžić u ovom djelu tretira sve relevantne činjenice $u$ vezi sa terminologijom hadisa, hadiske znanosti i njihovu podjelu. Ovo Handžićevo djelo štampano je više puta. ${ }^{14}$ Handžić je 1932. godine napisao i skraćenu verziju tog djela na arapskom jeziku. ${ }^{15}$

- Komentar djela: Tejsiru-l-vusul ila Džami'u-l-usul min hadisir-Resul, sallallahu 'alejhi ve sellem: To je komentar poznatog djela Ibn-Dejbe'a eš-Šejbanija (umro 944. god). Ustvari, to je samo dio ovog djela. ${ }^{16}$ Handžić je u dva velika sveska, na ukupno 541 velikom listu obradio to djelo do trećeg odjeljka drugog poglavlja: Fi bej'i-Ssimari ve-z-zuru'i. Na završetku drugog sveska, koji sadrži ukupno 408 rukom pisana lista, on navodi da ga je priveo kraju 13. ša'bana 1348. god. po Hidžri, što odgovara 1930. godini.

Drugi svezak, obzirom da ga nije završio, ne sadrži podatke o vremenu kada je pisan. Očito je, međutim, da je i taj svezak nastao u tom razdoblju. ${ }^{17}$

- Izharu-l-behadže, bi šerhi Sunen Ibn Madže: To je Handžićev komentar na najpoznatije Ibn-Madžino djelo Es-Sunen. U uvodu, Handžić naglašava da želi ukratko komentirati to značajno hadisko djelo, navodeći ocjenu za svaki hadis

Čitajući ovaj komentar Sunena na arapskom jeziku, pomislili bismo, da nema Handžićevog potpisa, da se radi o nekom od klasičnih

13 Vidi: Novi Behar, I/1927-1928, br. 22, str. 346-347; Karić i Demirović, Reis Džemaludin Čaušević - prosvjetitelj i reformator, II/603 i, Š. Kurdić, Apokrifni hadisi, str. 33 .

Inače, cjelovit tekst ovog rada iz Novog Behara, Karić i Demirović su uvrstili u dvotomnu knjigu o Džemaluddinu Čauševiću. (Vidi: Reis Džemaludin Čaušević prosvjetitelj i reformator, II/141-145)

${ }^{14}$ Vidi, na pr., izdanje Gazi Husrev-begove medrese, Sarajevo, 1968. godine.

${ }^{15}$ Vidi rukopis koji se čuva u Gazi Husrev-begovoj biblioteci pod red. br. 6967.

${ }^{16} \mathrm{O}$ tom djelu vidi: Kasim Dobrača, Katalog arapskih, turskih i perzijskih rukopisa, 1/384-385.

${ }^{17}$ Prvi svezak tog značajnog djela pohranjen je u Gazi Husrev-begovoj biblioteci u Sarajevu pod br. T. 203, a drugi svezak u istoj biblioteci pod br. T. 164. 
hadiskih velikana. Nije se tome ni čuditi, kada se zna da je Handžić konstantno iščitavao njihova djela i bio pod njihovim uticajem. Prava je šteta što Handžić to djelo, koje je efektno započeo, nije i završio. ${ }^{18}$ $\mathrm{Na}$ 118. listu je stao, došavši do poglavlja: Babu-r-redžuli jeste'inu 'ala vuduihi fejesubbu 'alejhi. ${ }^{19}$

- Es-Sunne: To je komentar 41 hadisa koje je Handžić sačinio na bosanskome jeziku. Ustvari, hadise je Handžić preuzeo od imama Nevevija i tim redoslijedom ih i komentirao. Čitavši njegove komentare, nedvojbeno se dolazi do zaključka o utemeljenosti našeg velikana. Naime, svakoj rečenici ovog komentara utemeljenje se može naći u Kur'anu i sunnetu!

Ovo djelo zapravo predstavlja komentiranje hadisa koje je dugo vremena objavljivao u tuzlanskom Hikjmetu, a kasnije je štampano kao zasebno djelo i to više puta. ${ }^{20}$

- Komentar na djelo: Hajatu-l-enbija' Ebu-Bekra Ahmeda b. elHusejna el-Bejhekija: To djelo Handžić je objavio još za vrijeme studija na Al-Azharu u Kairu. U njemu je, pored kraćeg komentara, valorizirao hadise koje je hafiz El-Bejheki spomenuo u ovom malom djelu. Štampano je u Egiptu 1349/1930. godine. $^{21}$

- Komentar na djelo: El-Kelimu-t-tajjib min ezkari-n-Nebijj, šejhu-l-islama Ibn Tejmijje: Ovo djelo Handžić je napisao, također, za vrijeme studija u Kairu. U njemu je, kao i kod prethodnog djela, naveo izvore za svaki spomenuti hadis i, po potrebi, ukratko komentirao važnije stvari. Štampano je 1349/1930. godine u Kairu na arapskom jeziku. $^{22}$

\footnotetext{
${ }^{18}$ Upravo na rahm. Handžiću i njegovom doprinosu sa posebnim osvrtom na ovo djelo odbranio je doktorsku disertaciju dr. Zuhdija Hasanović na Fakultetu islamskih nauka u Sarajevu.

${ }^{19}$ To Handžićevo djelo čuva se u Gazi Husrev-begovoj biblioteci u Sarajevu, pod inv. brojem 6.963 .

${ }^{20}$ Vidi, npr, sarajevsko izdanje iz 1968. god.

21 Vidi o tom djelu: hfz. Mahmud Traljić, Bibliografija radova $h$. Mehmeda Handžića od 1928-1940, El-Hidaje, IV, br. 4-5, Sarajevo 1941. Rad je poslije štampan kao separat u Državnoj štampariji, Sarajevo, 1941. god.

${ }^{22}$ Vidi: hfz. Mahmud Traljić, Bibliografija radova hadži Mehmed-ef. Handžića, Zbornik radova sa znanstvenih skupova o hadži Mehmedu Handžiću, Sarajevo, 1996, str. 131. Vidi, također: Esad Duraković, Bibliografija radova Mehmeda Handžića, Izabrana djela, 6/437.
} 
- Temelji hadiske nauke. Autor je Muhammed Tufo (18851939). On je bio poznavalac raznih islamskih disciplina, a posebno je, kako to potcrtava hfz. Mahmud Traljić, volio i pročuvao hadis islamsku tradiciju. ${ }^{23}$ Ovo djelo je Muhammed Tufo objavljivao u Glasniku IVZ tokom 1938. godine.

Pored ovog vrijednog djela, Tufo je u krugu svojih prijatelja i ljubitelja islamske znanosti preveo i protumačio nekoliko djela iz područja islamskih disciplina, a jedno od njih je hadisko djelo $A l$-Š ${ }^{\prime} f a^{\prime}$ bi ta'rif huquq al-Mustafa, autora Al-Qadi 'Iyada (umro 544. god) ${ }^{24} \mathrm{u}$ kojem je spomenut veliki broj hadisa u kojima se opisuju osobine i vrline posljednjeg Allahovog poslanika Muhammeda, s.a.v.s.

\section{DOPRINOS BOŠNJAKA HADISKOJ ZNANOSTI NAKON DRUGOG SVJETSKOG RATA DO DANAS}

U ovom vremenskom periodu intenziviran je spisateljski rad u oblasti hadisa i hadiskih disciplina. Pored stalnog predmeta koji je izučavan u Gazi Husrev-begovoj medresi, kao i ostalim novim ili obnovljenim medresama u Tuzli, Mostaru, Travniku, Visokom, Cazinu, N. Pazaru i Zagrebu, kao i pored brojnih predavanja i katedri iz ove discipline, u brojnim džamijama širom Bosne i Hercegovine i Sandžaka, nastalo je mnogo autorskih ili prevedenih djela iz ove oblasti.

Naročito je primjetan angažman Bošnjaka nakon agresije na Bosnu i Hercegovinu 1992 -1995. godine, a posebno u prevođenju i komentiranju različitih hadiskih zbirki, ali i djela iz oblasti osnova hadisa, njegove teorije i terminologije.

Stotine članaka i tekstova objavljeno je u ovom periodu iz različitih hadiskih disciplina u brojnim listovima i časopisima. Zbog ograničenosti prostora, mi ćemo navesti samo knjige koje su napisane ili prevedene u tom periodu.

${ }^{23}$ Provjeri: M. Traljić, Istaknuti Bošnjaci, str. 335 - 338.

${ }^{24}$ Al-Qadi 'Iyad je bio jedan od velikih islamskih učenjaka iz današnje Španije. 


\section{a) Prijevodi hadiskih zbirki} Hadžić. ${ }^{25}$

- Sažetak Buharijine zbirke hadisa preveo je Mehmedalija

- Muslimova zbirka hadisa. Do sada je prevedena dva puta. Prvi prevod je nastao 2003. god. ${ }^{26}$ Prevodilac je Šefik Kurdić, a drugi prevod je nastao godinu dana kasnije, a preveli su ga: Muhamed Mrahorović, Mustafa Prljača, Nurko i Jusuf Karaman i Aida Mujezin. ${ }^{27}$

U oba slučaja radi se o sažecima ove zbirke, koju je sačinio hafiz El-Muniziri.

Treba napomenuti da se često u našoj literaturi spominje da je Muslimovu zbirku hadisa prvi preveo Šefket ef. Šabić (1910 - 1975) iz Tuzle. Međutim, to su očito samo nagađanja i pretpostavke, jer nikada nije pronađen, niti javnosti na uvid predstavljen ovaj prevod. Hrvačić ${ }^{28}$

- Nesaijeva zbirka hadisa. Dio zbirke je preveo hfz. Dževad

- Malikov Muvetta'. Ovu zbirku preveo je mr. Hamid Indžić.

- Ahmedov Musned. Prevodilac Semir Rebronja. Do sada su štampana dva toma, 2010. i 2011. godine. ${ }^{29}$

- Rijadu-s-salihin Imama Nevevija dva puta je preveden na bosanski jezik. Prvi put je to učinio rahm. šejh Mustafa ef. Čolić 1974. god., ${ }^{30}$ a nakon njega to je učinila ekipa pevodilaca koju su sačinjavali Fuad Sedić, Šukrija Ramić, Zuhdija Adilović, Ibrahim Husić i Husejn Omerspahić, tadašnji studenti u Rijadu. ${ }^{31}$

\footnotetext{
${ }^{25}$ Ovaj sažetak štampan je 2005. god. u izdanju El-Kalema u Sarajevu.

${ }^{26}$ Izdavač je bila Kuća mudrosti iz Zenice.

${ }^{27}$ Izdavač je bio El-Kalem iz Sarajeva.

${ }^{28}$ Izdavač je Medžlis IZ Sanski Most.

${ }^{29}$ Izdavač je prevodilac.

${ }^{30}$ Ovo djelo je prevedeno za potrebe imama i štampano je šapirografom, tako da nikada nije doživjelo zvanično izdanje. Međutim, i pored toga, ovo djelo je izuzetno mnogo korišteno od strane imama i drugih čitalaca, jer je nastalo u vremenu kada je ova vrsta literature bila oskudna.

${ }^{31}$ Ovo djelo je štampano prvi put u Zagrebu 1993. god., a nakon toga doživjelo je veliki broj izdanja i sigurno je djelo koje je štampano u najvećem tiražu od svih hadiskih djela koja su se do sada pojavila na bosanskome jeziku.
} 
- Knjiga o edebu. Ovo je, ustvari, El-Edebu-l-mufred, poznato djelo Imama Buharija, u kojem je uvrstio hadise isključivo iz oblasti bontona i kulture ponašanja jednog muslimana. Djelo je preveo Armin Abaza 2009. godine. ${ }^{32}$

- Musned Ebu Hanife. Djelo je preveo dr. Fuad Sedić. ${ }^{33}$

- Et-Tergibu ve-t-terhib/Poticaji i upozorenja. Autor je poznati hafiz hadisa El-Muniziri. Djelo predstavlja skraćenu verziju četvorotomne knjige istoga naziva. Ovo je skraćena verzija od 858 hadisa, a nju je preveo dr. Sulejman Topoljak. ${ }^{34}$

- Vrline Allahovog Poslanika. To je poznato djelo Eš-Šemailu-lmuhamedijje Imama Tirmizije, $\mathrm{u}$ kojem su navođeni hadisi koji tretiraju Vjerovjesnikove duhovne i fizičke vrline i osobine. Djelo je na bosanski preveo mr. Husejn Omerspahić, 1995. godine i doživjelo je više izdanja. ${ }^{35}$

- Bin bir hadis, Mehmeda Arifa. Djelo je preveo hfz. Fuad ef. Subašić. ${ }^{36}$ Djelo, ustvari, predstavlja izbor 1001 hadis koje je Mehmed Arif preuzeo iz Sujutijeve zbrirke hadisa poznate pod imenom Džami'u-s-sagir.

- Vrhunac čežnje za šerijatskim dokazima. Ovo je, ustvari, poznato djelo Bulugu-l-meram hafiza Ibn-Hadžera el-Askalanija, u kojem navodi 1.500 hadisa koji predstavljaju argumente islamskih učenjaka za njihove stavove u šerijatskom pravu. Djelo je preveo hfz. Emir Čajić 2011. godine. ${ }^{37}$

- Cvjetovi iz Muhammedove, a.s., bašče. Autor je Muhammed Jusuf Kandehlevi. Ova knjiga predstavlja izbor hadisa, kako je autor naveo, iz najvjerodostojnijih zbirki. Prevodilac je dr. Džemaluddin Latić. $^{38}$

\footnotetext{
${ }^{32}$ Izdavač je Islamski kultruni centar iz Mostara.

${ }^{33}$ Djelo je doživjelo dva izdanja: 2007. godine izdavač je bio Islamski pedagoški fakultet u Bihaću, a 2011. El-Kelimeh iz N. Pazara.

${ }^{34}$ Izdavač je Bookline, Sarajevo, 2004.

${ }^{35}$ Izdavač je El-Kalem.

36 Djelo je štampao prvo Medžlis IZ Bužim 1991. godine a zatim i Islamska pedagoška akademija u Bihaću 2000. godine.

${ }^{37}$ Izavač je El-Kelimeh iz N. Pazara.

${ }^{38}$ Izdavač je Sova - Publishing, Sarajevo, 2009. godine.
} 
- 77 hadisi-kudsijja. Preveo Fikret Pašanović. ${ }^{39}$

Biseri Vjerovjesničke mudrosti. U ovo djelo Salih Indžić je uvrstio 1.119 hadisa i objavio 2001. godine. ${ }^{40}$

- Lijepa riječ. Ovo je zbirka od 193 vjerodostojna hadisa koji aktualiziraju lijepu riječ izgovorenu, uglavnom, kroz dove i zikr, koji se prenose od Allahovog Poslanika, s.a.v.s. Autor je Ibn-Tejmijje a zbriku je s arapskog preveo Dževad Hot. ${ }^{41}$

- Zlatni lanac prenosilaca. Autor je dr. Fuad Sedić. ${ }^{42}$ Naveo je 91 hadis koji je prenesen tzv. zlatnim lancem prenosilaca, a to je po većini hadiskih eksperta, niz u kojem Malik prenosi od Nafi'a, a on od Abdullaha b. Omera, r.a.

\section{b) Zbirke hadisa s komentarom}

- Buharijina zbirka hadisa. Ovu najpoznatiju i najautentičniju zbirku hadisa prvi je, u cjelosti, na Bosanski jezik preveo hfz. Fuad ef. Subašić. Međutim, ova zbirka do danas nije štampana. ${ }^{43}$

- Prva tri i početak četvrtog dijela ove zbirke preveo je i objavio Hasan Škapur, ${ }^{44}$ a njegov posao je nastavio Hasan Makić, ${ }^{45}$ da bi preostalu polovinu Zbirke prevela grupa prevodilaca, među kojima su bili: Hasan Makić, hfz. Haso Popara, mr. Ibrahim Husić, mr. Muhamed Mehanović, dr. Muharem Štulanović, dr. Šukrija Ramić, dr. Šefik Kurdić, dr. Zuhdija Adilović i dr. Ahmed Adilović. ${ }^{46}$

\footnotetext{
${ }^{39}$ Djelo je štampano u Gračanici 1991. god.

${ }^{40}$ Izdavač je Elči Ibrahim-pašina medresa Travnik.

${ }^{41}$ Izdavači su NABA, Visoko, 2001. godine i El-Kelimeh, N. Pazar, 2005. godine.

${ }^{42}$ Djelo je štampano u izdanju Islamske pedagoške akademije u Bihaću, 2003. godine.

${ }^{43}$ Ova zbirka u prijevodu hfz Fuada ef. Subašića dostupna je na internet-adresi: http://www.i-mos.ch/buharie.

${ }^{44}$ Prvi tom je štampan 1974; drugi 1975 a treći 1976. godine.

${ }^{45}$ Četvrti tom je štampan 1990. godine.

${ }^{46}$ Cjelovitu zbirku objavio je Visoki saudijski komitet za pomoć BiH i Kulturni centar Kralj Fahd u Sarajevu, 2008. godine.
} 
- Tirmizijina zbirka hadisa. Ovo djelo preveo je i komentirao prof. Mahmud Karalić. Djelo je prvi put objavljeno u periodu od 1999. $-2004 .{ }^{47}$ a drugo izdanje je objavljeno u sedam tomova 2010. god. ${ }^{48}$

- Ebu Davudova zbirka hadisa. Prevedena su prva dva toma. Prevodilac i komentator ovog djela je prof. Mahmud Karalić. Do sada je preveo dva toma, ali djelo još nije štampano. ${ }^{49}$

- Subul as-salam od Imama Es-San'anija. Preveo dr. Omer Nakičević. ${ }^{50}$

- Biseri Poslanikove, a.s., mudrosti. Izbor, prijevod i komentar sačinio je Mustafa Hadžić i objavio 1999. godine. ${ }^{51}$ Preveo je i komentirao 34 hadisa.

- Mali predznaci Sudnjeg dana. Zbirka hadisa s komentarom o malim predznacima Sudnjega dana. Autor je dr. Fuad Sedić. ${ }^{52}$

- Vrijednost $i$ ljepote hadža. Zbrika hadisa o hadžu s komentarom. Autor je Šefik Kurdić. Djelo sadrži 135 vjerodostojnih hadisa o tajnama, vrednotama i ljepotama hadža i hadžskih obreda. ${ }^{53}$

- Broj 40 u hadisima Allahovog Poslanika, s.a.v.s. Izbor, prijevod i komentar hadisa sačinio je Mirsad ef. Sedić. ${ }^{54}$

- Vjerovanje (iman-islam). Autor je Ibn-Dejbe' eš-Šejbani. Ovdje se radi o jednom dijelu njegove zbirke hadisa, poznate kao Tejsiru-l-vusul. Dio ovog kapitalnog djela je preveo i komentirao Fuad Sedic. ${ }^{55}$

\footnotetext{
${ }^{47}$ Izdavač je Elči Ibrahim-pašina medresa u Travniku.

${ }^{48}$ Izdavač je El-Kelimeh iz Novog Pazara.

${ }^{49}$ Prvi tom je u pripremi za štampu, u izdanju El-Kelimeh iz N. Pazara.

${ }^{50}$ Izdavač FIN, Sarajevo, 2003. godine.

${ }^{51}$ Izdavač je BZK ,Preporod“ Zenica.

${ }^{52}$ Djelo je prvi put štampano 1996. god. u izdanju Aktivne islamske omladine.

${ }^{53}$ Izdavač je El-Kelimeh, N. Pazar, 2011. godine.

${ }^{54}$ Izdavač je Islamska pedagoška akademija, Bihać, 2003.

${ }^{55}$ Izdavač je Ujedinjeni komitet Emirata za pomoć BiH i Et-Takva-internacional, Bihać, 1993.
} 
- Poslanikova, s.a.v.s., preskazanja. Izbor i komentar hadisa o predznacima i predskazanjima Allahovog Poslanika, s.a.v.s., sačinio je mr. Esmir Halilović. ${ }^{56}$

- Apokrifni hadisi. Autor je Šefik Kurdić. ${ }^{57}$ Ovo, ustvari, predstavlja zbirku lažnih hadisa koji se upotrebljavaju u govoru ili literaturi kod Bošnjaka i ona je prva knjiga ovakve vrste na bosanskome jeziku, koja eksplicite upozorava na opasnost i štetnost citiranja ovakvih predanja pod plaštom hadisa.

\section{c) Zbirke četrdeset hadisa}

- Četrdeset odabranih hadisa. Autor je dr. Fuad Sedić. ${ }^{58}$

- 40 kudsi hadisa. Preveo Husejn Omerspahić 1997. godine. ${ }^{59}$

\section{d) Zbirke četrdeset hadisa s komentarom}

- Es-Sunne. Djelo sadrži 41 preveden i protumačen hadis. Autor je Mehmed ef. Handžić.

- Buđenje ambicija. Četrdeset hadisa s komentarom. Djelo je preveo Husein Idris Ademi. ${ }^{60}$

- Četrdeset hadisa s tumačenjem. Aktualizirani su i komentirani hadisi iz različitih sfera života. Autor je dr. Adnan Silajdžić. ${ }^{61}$

- Moral muslimana Ahmeda Muaza Hakkija. To je zbirka četrdeset hadisa s komentarom. Prevodilac je Fahrudin Smailović. ${ }^{62}$

\section{e) Terminologija i teorija hadisa}

- Vjerovjesnikov Sunnet između šerijatskih pravnika $i$ znanstvenika hadisa šejha Muhammeda el-Gazalija, preveli su:

\footnotetext{
${ }^{56}$ Izdavač je autor, Zenica, 2010. godine.

${ }^{57}$ Djelo je štampano u izdanju El-Kelimeh iz N. Pazara, 2010. godine.

${ }^{58}$ Izdavač Islamska pedagoška akademija u Bihaću 2006. godine.

${ }^{59}$ Izdavač je El-Kalem.

${ }^{60}$ Izdavač je Bookline, Sarajevo, 2004. godine.

${ }^{61}$ Izdavač je Muftijstvo zeničko, 1993. godine.

${ }^{62}$ Djelo je štampao Bookline u Sarajevu, 2004. godine.
} 
Nermin Čanić, Zuhdija Hasanović i Osman Kozlić. ${ }^{63}$ U ovom djelu El-Gazali je pokušao ukazati na mnoga pogrešna tumačenja koja su vremenom infiltrirana $u$ hadis.

- Razumijevanje Sunneta - metodološke smjernice i pravila dr. Jusufa el-Karadavija. Djelo je preveo Ahmet Alibašić. ${ }^{64}$ Dr. ElKaradavi je u ovom djelu naveo temeljna uputstva kako ispravno i autentično razumijevati hadis Allahovog Poslanika, s.a.v.s.

- Vjerovjesnikov Sunnet Fethullaha Gulena. Djelo je preveo dr. Zuhdija Hasanović. ${ }^{65}$ Autor aktualizira u ovom djelu temeljnu hadisku terminologiju i osnovne hadiske discipline, navodeći brojne primjere iz Vjerovjesnikovog, s.a.v.s., hadisa i njihovo pogrešno razumijevanje od strane muslimana, podstičući ih na suštinsko razumijevanje, shodno razumijevanju prve generacije muslimana.

- Uvod u tefsirku i hadisku nauku. Autor je Mehmed Handžić. ${ }^{66}$ Ovo djelo koje aktualizira osnovna znanja iz oblasti tefsira i hadisa, dugo vremena je korišteno kao osnovna tefsirska i hadiska literatura za potrebe Gazi Husrev-begove, a kasnije i drugih medresa, iz predmeta tefsir i hadis.

- Uvod u hadiske znanosti. Autor je dr. Omer Nakićević. ${ }^{67}$ Djelo tretira osnove hadisa i temeljnu hadisku terminologiju i već dugo vremena se koristi kao udžbenik na predmetu hadis na islamskim visokoškolskim ustanovama.

- Velikani hadiskih znanosti. Autor dr. Šefik Kurdić. Djelo je objavljeno 2003. god. i u njemu su navedena 24 hadiska velikana. ${ }^{68}$ Među ovom plejadom muhaddisa, uvrštena su i dvojica predstavnika bosanske hadiske škole i to: Mustafa Pruščak, kao bosanski muhaddis iz osmanskog perioda i Mehmed ef. Handžić, kao predstavnik bosanske hadiske škole novijeg doba.

\footnotetext{
${ }^{63}$ Izdavač je Muftijstvo tuzlansko 1998. godine.

${ }^{64}$ Izdavač je Bemust, Sarajevo, 2001.

${ }^{65}$ Izdavač je El-Kalem 2009. godine.

${ }^{66}$ Izdavač je Gazi Husrev-begova medresa u Sarajevu, 1968. godine,a djelo je doživjelo više izdanja.

${ }^{67}$ Izdavač je FIN, Sarajevo, 1986. godine, a knjiga je doživjela više izdanja.

${ }^{68}$ Izdavač je Islamska pedagoška akademija u Zenici.
} 
- Hadis i hadiske znanosti. Autor je prof. Mahmut Karalić. ${ }^{69}$ Knjiga tretira temeljna područja i temeljne discipline hadisa.

- Rad h. Mehmed ef. Handžića na polju hadiskih znanosti s osvrtom na djelo Izharu-l-behadže bi šerh Sunen Ibn Madže. Ovo je objavljena doktorska disertacija dr. Zuhdije Hasanovića, predavača hadisa na FIN-u u Sarajevu. ${ }^{70}$

- Ebu Hanife i njegov doprinos hadiskoj znanosti. Autor je Šefik Kurdić. $^{71}$ U ovoj knjizi je apostrofiran Ebu-Hanifin doprinos ovoj znanosti i odagnane brojne špekulacije i insinuacije u pogledu njegovog slabog uvida u ovu islamsku disciplinu.

- Četiri velika imama i njihov doprinos hadiskoj znanosti. Autor je Šefik Kurdić. ${ }^{72}$ Djelo tretira angažman Ebu-Hanife, Malika, Šafije i Ahmeda na planu hadisa i hadiskih znanosti i njihov doprinos na afirmiranju riječi i djela posljednjeg Allahovog poslanika, Muhammeda, s.a.v.s.

- Povodi nastanka nekih hadisa. Autor Mirsad Mahmutović.73 To je, ustvari, sažetak Ibn-Hamzinog djela iz ove oblasti, poznatog pod nazivom El-Bejanu ve-t-ta'rifu fi esbabi vurudi-l-hadisi.

- Bazi hadis meseleleri uzrinde tetkikleri' što bi u prevodu značilo "Naučno istraživanje o nekim hadiskim problemima'. Autor je Tajib Okić. ${ }^{74}$ Djelo je pisano turskim jezikom, jer je autor predavao hadis na Ilahijjat fakultetu u Ankari, čiji je bio i utemeljitelj i dugo vremena dekan i tretira hadisku terminologiju i temelje hadiske znanosti.

- Tefsir ve hadis usulunun bazi meseleleri, što bi u prevodu značilo 'Neka pitanja iz osnova tefsira i hadisa'. Autor je Tajib Okić. ${ }^{75}$ Ovo djelo, kao što se može zaključiti iz samog naziva, sastoji se iz dva dijela. Prvi dio se odnosi na tefsir a drugi na hadis i hadisku znanost.

\footnotetext{
${ }^{69}$ Knjigu je objavila Izdavačka kuća El-Kelimeh iz N. Pazara 2010. godine.

${ }^{70}$ Izdavač je FIN i El-Kalem, Sarajevo, 2004. godine.

${ }^{71}$ Izdavač je El-Kelimeh, Novi Pazar, 2007. godine.

${ }^{72}$ Izdavač je Islamski pedagoški fakultet Univerziteta u Zenici, 2011. godine.

${ }^{73}$ Djelo je štampano u Visokom, 1993. godine.

${ }^{74}$ Ovo djelo je štampano 1959. godine u Ankari.

${ }^{75}$ Ova knjiga je objavljena 1995. godine u Ankari.
} 
Ne treba zaboraviti da je, također, napisan jedan broj udžbenika za potrebe naših medresa iz ove oblasti.

\section{NAJIZRAZITIJI PREDSTVANIK BOŠNJAČKE ŠKOLE HADISA}

Mehmed Handžić (1906. - 1944.) je bio, zasigurno, najmarkantnija ličnost u ovom periodu kada je u pitanju hadis $i$ njegove discipline. On je bio takav velikan u čijoj su osobi, može se slobodno konstatirati, ostvarena etička, duhovna i intelektualna paradigma i uspostavljena iznutarnja nacionalna vertikala Bošnjaka. Za razliku od moderniste Čauševića, Handžić je bio tradicionalista. Dok je Čaušević htio obnoviti naše institucije i onim postignućima koja nam dolaze iz Evrope, što je za bosanske muslimane značilo neminovnu modernizaciju, dotle je Handžić htio obnoviti našu bosansku islamsku sadašnjost iz sigurne i provjerene tradicije i pouzdane prošlosti. ${ }^{76}$

Handžićev opus u domenu hadisa $\mathrm{i}$ hadiskih znanosti bio je impozantan. Njegova djela na arapskom i bosanskom jeziku postala su nezaobilazni izvori u ovoj disciplini. Svojim pristupom ovoj disciplini i izuzetnom utemeljenošću postao je paradigma potonjim generacijama Bošnjaka.

Spisateljski angažman ovog našeg velikana bio je, doista, fascinantan. Iako je napisao veliki broj djela i tekstova u različitim disciplinama, ipak se najviše naglasio u hadisu i hadiskoj znanosti koje je najviše volio i posebno proučavao.

Njegovo interesiranje za hadis Allahovog Poslanika, s.a.v.s, briga da se hadis očuva i pravilno prezentira bošnjačkom narodu, rezultirali su nekolicinom značajnih djela kojima se mi, Bošnjaci, moramo itekako ponositi.

Handžićevo zanimanje za hadis i hadiske znanosti u djelima i tekstovima kojima raspolažemo seže od teorije hadisa, njegove sistematizacije i kategorizacije, pa sve do komentiranja brojnih

\footnotetext{
${ }^{76}$ Opširnije o njegovom stavu i metodama rada vidi izvanrednu studiju: dr. Esad Duraković, Prosvjetiteljski zanos Handžićev, Izabrana djela Mehmeda Handžića, knjiga I, Ogledalo, Sarajevo, 1999, str. 5-31.
} 
Poslanikovih, s.a.v.s, riječi i njihova približavanja praktičnoj primjeni. $^{77}$

\section{ZAKLJUČAK}

$\mathrm{Na}$ temelju izloženog može se konstatirati da je angažman bošnjačkih intelektualaca na području hadisa i hadiskih znanosti bio značajan. U periodu između vladavine Austro-Ugarske monarhije u BiH i Prvog svjetskog rata, angažiranost Bošnjaka u ovoj oblasti nije bila posebno izražena. Međutim, nije to slučaj samo sa hadisom i hadiskim disciplinama, isti je, uglavnom, odnos bio i prema drugim naučnim disciplinama, jer se $\mathrm{BiH}$ našla u jednoj specifičnoj situaciji, o čemu je bilo govora u ovom radu.

Međutim, interesiranje za ovu oblast u periodu između dva svjetska rata itekako je intenziviran, posebno radom i pregalaštvom Mehmeda ef. Handžića, najvećeg muhaddisa kojeg je $\mathrm{BiH}$ iznjedrila, a ta briga za drugi izvor šerijatskog prava bila je prepoznatljiva i kroz česte napise, konkretno iz ove oblasti u časopisima Hikjmet i ElHidaje.

Međutim, očito je iz navedenog teksta, da je najveći angažman Bošnjaka na afirmiranju hadisa i hadiskih znanosti manifestiran $u$ periodu nakon Drugog svjetskog rata, a posebno nakon agresije na $\mathrm{BiH}$ 1993. godine. Tada je nastalo najviše autorskih radova i prevoda različitih hadiskih djela, a posebno najautentičnijih hadiskih zbirki.

\section{Literatura:}

- Knjige

1. Ahmed b. Hanbel, Musned, s arapskog: Semir Rebronja, N. Pazar, 2010.

2. Arif, Mehmed, Hiljadu i jedan hadis, s arapskog: fhz. Fuad Subašić, Odbor IZ Bužim, 1991. i IPA, Bihać, 2000.

3. Bašagić, dr Safvet-beg, Bošnjaci i Hercegovci u islamskoj književnosti, Svjetlost, Sarajevo, 1986.

4. Džanko, Muhidin, Safvet-beg Bašagić, Sarajevo, 2006.

77 Opširnije o Handžiću i njegovom spisateljskom opusu u hadiskoj znanosti: S̆. Kurdić, Velikani hadiskih znanosti, str. 376-386. 
5. El-Buhari, Muhammed b. Isma'il, Knjiga o edebu, s arapskog: Armin Abaza, Islamaski kulturni centar, Mostar, 2009.

6. El-Gazali, Muhammed, Vjerovjesnikov Sunnet između šerijatskih pravnika $i$ znanstvenika hadisa, Muftijstvo tuzlansko, Tuzla, 1998.

7. Gulen, Fehullah, Vjerovjesnikov Sunnet - važnost i razumijevanje, El-Kalem, Sarajevo, 2009.

8. El-Karadavi, dr. Jusuf, Razumijevanje Sunneta - metodološke smjernice $i$ pravila, Bemust, Sarajevo, 2001.

9. El-Munziri, hafiz Abdulazim, Et-Tergibu ve-t-terhib - Poticaji i upozorenja, s arapskog: dr Sulejman Topoljak, Bookline, Sarajevo, 2004.

10. En-Nesai, Ebu Abdurrahman, Nesaijeva zbirka hadisa, s arapskog: hfz. Dževad Hrvačić, Medžlis IZ Sanski Most, 2005.

11. Es-San'ani, Muhammed b. Isma'il, Subul as-salam, s arapskog: dr. Omer Nakičević, FIN, Sarajevo, 2003.

12. Eš-Šejbani, Ibn Dejbe', Vjerovanje (iman-islam), Ujedinjeni komitet Emirata za pomoć BiH i Takva-internacional, Bihać, 1993.

13. Hadžić, Mustafa, Biseri Poslanikove, a.s., mudrosti, BZK Preporod, Zenica, 1999.

14. Hakki, Ahmed Muaz, Moral muslimana (četrdeset hadisa o moralu s komentarom), s arapskog: Fahrudin Smailović, Bookline, Sarajevo, 2004.

15. Handžić, Mehmed, Izabrana djela, Ogledalo, Sarajevo, 1999.

16. Hasanović, dr. Zuhdija, Rad h. Mehmed ef. Handžića na polju hadiskih znanosti s osvrtom na djelo Izharu-l-behadže bi šerh Sunen Ibn Madže, FIN i El-Kalem, Sarajevo, 2004.

17. Ibn Redžeb el-Hanbeli, Buđenje ambicija, s arapskog: Husein Idris Ademi, Bookline, Sarajevo, 2004.

18. Ibn Tejmijje, Lijepa riječ, s arapskog: Dževad Hot, NABA, Visoko, 2001. i ElKelimeh, N. Pazar, 2005.

19. Indžić, Salih, Biseri vjerovjesničke mudrosti, Elči Ibrahim-pašina medresa, Travnik, 2001.

20. Karalić, Mahmut, Hadis i hadiske znanosti, El-Kelimeh, N. Pazar, 2010.

21. Karić, dr. Enes i Demirović, dr. Mujo, Reis Džemaludin Čaušević - prosvjetitelj $i$ reformator, Ljiljan, Sarajevo, 2002.

22. Kurdić, Šefik, Al-Inaya bi al-hadith fi al-Bosna munzu fathiha ila awahir al-qar al- išrin, neobjavljena doktorska disertacija, odbranjena na Univerzitetu AlZaituna u Tunisu, 1997. god. 
23. Kurdić, Šefik, Apokrifni hadisi - zbirka lažnih hadisa, El-Kelimeh, N.Pazar, 2010.

24. Kurdić, Šefik, Četiri velika imama i njihov doprinos hadiskoj znanosti, Islamski pedagoški fakultet, Zenica, 2011.

25. Kurdić, Šefik, Ebu Hanife i njegov doprinos hadiskoj znanosti, El-Kelime, N. Pazar, 2007.

26. Kurdić, Šefik, Velikani hadiskih znanosti, Islamska pedagoška akademija, Zenica, 2003.

27. Muslim, Muslimova zbirka hadisa, s arapskog: Šefik Kurdić, Kuća mudrosti, Zenica, 2003.

28. Okić, M. Tajib, Islamska tradicija, Sarajevo, 1936.

29. Sedić, Fuad, Mali predznaci Sudnjeg dana, AIO BiH, 1996.

30. Sedić, Fuad, Zlatni lanac prenosilaca, IPA, Bihać, 2003.

31. Sedić, Mirsad, Broj 40 u hadisima Allahovog Poslanika, s.a.v.s., Islamska pedagoška akademija, Bihać, 2003.

32. Silajdžić, Adnan, 40 hadisa s tumačenjem, Muftijstvo zeničko, 1993.

33. Tirmizi, Ebu 'Isa, Tirmizijina zbirka hadisa, s arapskog: Mahmut Karalić, Elči Ibrahim-pašina medresa, Travnik, 1999-2009 i El-Kelimeh, N. Pazar, 2010.

34. Tirmizi, Ebu 'Isa, Vrline Allahovog Poslanika, s.a.v.s., s arapaskog: mr. Husejn Omerspahić, El-Kalem, Sarajevo, 1995.

35. Traljić, hfz. Mahmud, Istaknuti Bošnjaci, El-Kalem, Sarajevo, 1998.

\section{-Periodika}

36. - Novi Behar, br. 19-21, Sarajevo, 1933-34. god., 
Sefik Kurdic, Ph D

BOSNIAKS AND HADITH SINCE THE AUSTRO-HUNGARIAN OCCUPATION OF BOSNIA AND HERZEGOVINA UNTIL THE PRESENT TIMES

\section{SUMMARY}

Hadith and the science of Hadith have been defined completely after the arrival of the Ottomans in the Bosnia and the Islamization of these region. If we look through the prism of written works on the theory of Hadith, Hadith terminology, the completion of numerous collections of Hadith, and more, we can conclude that the Bosniak intellectuals were not satisfied with only this effort, but have given their contribution in this scientific field through their curiosity and intellectual resources.

This article attempts to highlight the involvement of Bosniaks in the field of Hadith and the disciplines of Hadith from the AustroHungarian occupation of Bosnia and Herzegovina until today. It proves that the Bosnians, although a small nation, did not lagg behind other nations in terms of their interest in Islamic disciplines, especially the Hadith, its preservation and its transmission to the following generations.

Keywords: Hadith, the sciences of Hadith, Bosniaks, period of the Austro-Hungarian rule, the period after the Austro-Hungarian rule 
الأستاذ الدكتور شفيق كورديتش

البشانقة والحديث النبوي من احتلال النمساوي - المجري للبوسنة والهرسك إلى اليوم

\section{خلاصهة البحث}

وإن تم تحديد علم الحديث ومصطلح الحديث بشكل كامل بقدوم العثمانيين

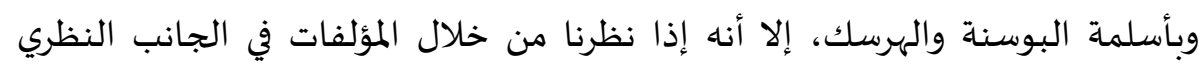

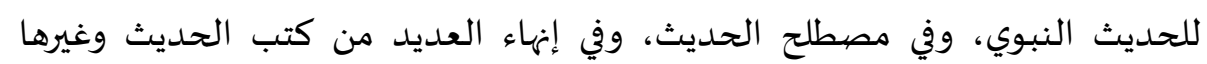

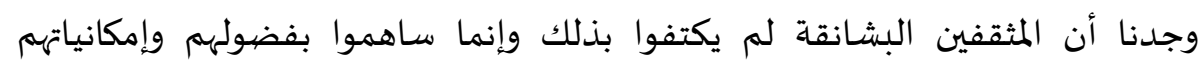
العقلية في هذا المجال العلمي أيضاً.

هذا النص يحاول تسليط الضوء على مساهمة البشانقة في مجال الحديث وعلوم الحديث من زمن احتلال النمساوي - المجري للبوسنة إلى يومنا هذا. إنه يبرهن

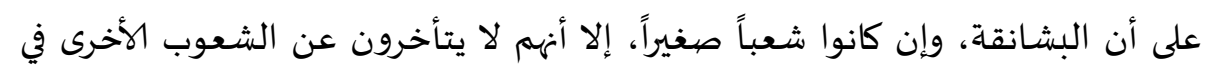

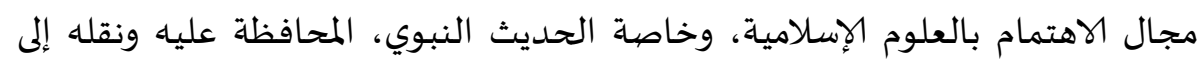
الأجيال القادمة.

الكلمات الرئيسة: الحديث النبوي، علوم الحديث، البشانقة، زمن الحكم

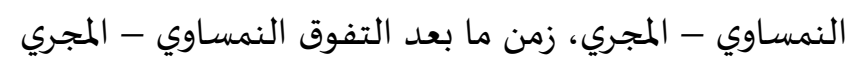

